\title{
PERISTIWA PENTAKOSTA DIPANDANG DARI PERSPEKTIF TEOLOGI YANG TRANSFORMATIF
}

\author{
Dio A. Pradipta \\ Sekolah Tinggi Teologi Bethel Indonesia, dioapradipta@sttbi.ac.id
}

\begin{abstract}
The Pentecostal events that took place in the Acts 2, are believed to be the fulfillment of the prophecy of the prophet Joel (Joel 2: 28-32); at least, that is the Pentecostals' perspective today. The problem that arises is that often the outpouring of the Holy Spirit is not seen as a precursor of change or transformation whether it is individual or ecclesiological (liturgical worship). People tend to ignore the contribution of Holy Spirit in the life of believers. The resurrection of Jesus Christ is indeed a very important event, but Pentecost is what drives the apostles to be witnesses of Christ. In this paper, we try to describe the impact of the outpouring of the Holy Spirit in Acts 2: 1-4 in two aspects namely the narrow (personal) aspect, and broad (ecclesiological) aspect. In a narrow aspect, Pentecost changes the lives of believers as empowerment for mission and the starting point for changing the character of believers in a positive direction. In a broad aspect, it turns out that the outpouring of the Holy Spirit also brought changes to the liturgy of the great worship that is seen today at Pentecostal vs. worship. non-Pentakota. Researchers argue, the striking difference is because the Pentecostals' response to the outpouring of the Holy Spirit itself is very accommodating and responsive. Pentecost worship is a worship that is sensitive to the empowerment of the Holy Spirit manifested in spiritual gifts. These spiritual gifts have a significant impact on communal growth.
\end{abstract}

Keywords: pentecost; transformation; ecclesiology; pneumatology; holy spirit

\begin{abstract}
Abstrak
Peristiwa Pentakosta yang terjadi di Kisah Para Rasul pasal yang ke-2, diyakini sebagai penggenapan nubuatan nabi Yoel (Yl. 2:28-32); setidaknya, itulah perspektif kaum Pentakosta sekarang ini. Permasalahan yang timbul adalah seringkali pencurahan Roh Kudus tidak dipandang sebagai sebuah prekursor atas perubahan atau transformasi baik itu bersifat individu maupun secara eklesiologi (liturgi ibadah). Pemahaman yang terlalu kritosentris cenderung mengabaikan sumbangsih pneumatologis di dalam kehidupan orang percaya. Kebangkitan Yesus Kristus memang peristiwa yang sangat penting, tetapi Pentakosta yang mendorong para rasul menjadi saksi Kristus. Di tulisan ini, peneliti berusaha menggambarkan dampak pencurahan Roh Kudus di dalam Kisah Para Rasul 2:1-4 di dalam dua aspek yaitu aspek yang sempit (pribadi), dan aspek yang luas (eklesiologi). Dalam aspek sempit, Pentakosta mengubahkan kehidupan orang percaya sebagai pemberdayaan untuk misi serta titik tolak perubahan karakter orang percaya ke arah yang positif. Dalam aspek luas, ternyata pencurahan Roh Kudus juga membawa perubahan pada liturgi ibadah raya yang sebagaimana dilihat sekarang ini di ibadah Pentakosta vs. non-Pentaksota. Peneliti berargumen, perbedaan mencolok adalah karena respons umat Pentakosta terhadap peristiwa pencurahan Roh Kudus sendiri yang sangat akomodatif dan responsif. Ibadah Pentakosta merupakan sebuah ibadah yang peka terhadap pemberdayaan Roh Kudus yang termanifestasi dalam karunia-karunia roh. Karunia roh tersebut memiliki dampak yang signifikan terhadap pertumbuhan komunal.
\end{abstract}

Kata Kunci: pentakosta; transformasi; eklesiologi; pneumatologi; roh kudus 


\section{PENDAHULUAN}

Tidak bisa dipungkiri bahwa peristiwa penggenapan nubuatan para nabi Perjanjian Lama mengenai pencurahan Roh Allah berhasil merubah tatanan kehidupan orang percaya, baik di masa lampau maupun masa sekarang. Bahkan pada zaman peristiwa Pentakosta di Kisah Para Rasul, turunnya Roh Kudus di tengahtengah para murid (Kis. 2:1-4), menghasilkan sebuah tanda-tanda eksternal yang dapat didengar oleh masyarakat sekitar tempat para rasul berdoa dan membuat mereka berkerumun (2:6). Kebingungan khalayak ramai semakin menjadi-jadi ketika di tengah siang hari, mereka mendengar para Rasul berbicara dengan Bahasa daerah mereka masingmasing $(2: 8-11){ }^{1}$

Ketika berbicara mengenai teologi transformatif, atau sebuah usaha berteologi yang membawa perubahan besar, pembaca dapat mengkategorikan dampak dari peristiwa Pentakosta ini menjadi 2 kategori: transformasi secara sempit dan luas. Peneliti memberikan definisi sendiri bahwa transformasi dalam arti sempit yaitu adanya perubahan yang tampak pada diri personal atau masing-masing individu dan artian luas adalah dampak yang dilihat secara eklesiologi atau gereja. Dampak peristiwa Pentakosta dalam arti yang lebih luas lagi yang menyangkut sebuah perubahan konkrit dalam berbudaya di luar jangkauan penelitian saat ini. Peneliti akan mendeskripsikan dampak peristiwa Pentakosta yang dialami dan dirasakan oleh para murid dan gereja saat itu, dan juga pada masa kini dimana Pentakosta juga mentransformasi tubuh Kristus.

\section{PEMBAHASAN}

Peristiwa Pentakosta dilihat ketika para murid menanti di suatu tempat untuk janji kuasa itu (Kis. 1:8,) dan para murid berdoa berhari-hari dan pada saat yang ditentukan turunlah Roh Kudus dengan sebuah manifestasi fisik yang terlihat "lidah api” dan bunyi angin yang keras. Para murid dipenuhi oleh Roh dengan tanda mereka berkata-kata dengan bahasa yang diberikan Roh kepada mereka masing-masing. Penting untuk diperhatikan bahwa Lukas mencatat "turunlah dari langit suatu bunyi..." (2:2) yang mengindikasikan pengalaman transenden dan juga secara spasial dapat dilihat dan dirasakan: dari atas turun ke bawah sini. ${ }^{2}$ Roh itu turun dari luar tubuh dan secara imanen berdiam di dalam para murid, menimbulkan manifestasi fisik yang terlihat juga. Hal ini penting karena pengalaman akan Roh itu semakin intens dirasa dalam lingkup ruang dan waktu yang temporal. $^{3}$ Dan pemahaman ini akan menjadi penting saat peneliti membahas transformasi dalam lingkup eklesiologi.

Salah satu yang paling mencolok dalam perubahan individu adalah Petrus yang dengan gagah berani berkotbah dan menantang masyarakat sekitar untuk 
bertobat dan menerima Yesus sebagai Tuhan dan Juruselamat (Kis. 2:14-36). Di dalam kotbah yang singkat ini, terkandung kuasa Roh Kudus yang membuat para pendengar "hati mereka sangat terharu" (ay. 37) dan mengambil tindakan nyata untuk bertobat, dibaptis, dan masuk ke dalam komunitas yang baru ini. Bahkan jika melihat bukti ayat Firman Tuhan yang ada, kehadiran peristiwa Pentakosta justru yang memulai era gereja mula-mula. Lebih lanjut bisa dikatakan, pelayanan Roh melalui dan bersama para orang percaya jauh lebih komprehensif dibanding sebelum peristiwa Pentakosta. $^{4}$

Bisa jadi ada counter-argument bahwa bukan peristiwa Pentakosta yang mentransformasi Petrus dan para murid, tetapi peristiwa kebangkitan Yesus dari maut sebagai prekursornya. Lukas dalam tulisannya memberikan argumen yang berbeda. Pada saat diberitahu tentang kebangkitan Yesus, para murid bersikap "bagi mereka perkataan-perkataan itu seakan-akan omong kosong dan mereka tidak percaya kepada perempuanperempuan itu" (Luk. 24:11). Petrus pun terkejut dan segera mencari kebenaran klaim itu hanya untuk, "bertanya dalam hatinya apa yang kiranya telah terjadi" (24:12). Lukas merangkum perasaan para murid "mereka belum percaya karena girangnya dan masih heran" (24:41). Di akhir suratnya, Lukas menulis para murid kembali ke Yerusalem dengan bersukacita atas antisipasi mereka tentang janji dari Bapa dan kuasa yang akan diberikan (24:49, 52-53). Jelas bagi Lukas, peristiwa Pentakosta yang berhasil mentransformasi para Rasul untuk berkotbah dengan berani dan memberikan rasa takut kepada pendengar (Kis. 2:43), berdiri di depan para mahkamah agama (4:5-22), dan memberitakan Injil dengan berani $(4: 31){ }^{5}$

$$
\text { Pentakosta mengakui bahwa janji }
$$
kuasa yang akan dicurahkan itulah (Kis. 1:8) yang menjadi titik pijak transformasi yang akan dialami oleh orang percaya dan juga gereja. Bahkan Menzies dan Horton menulis janji di dalam Kisah Para Rasul 1:8 tidak bisa hanya dikaitkan dengan pengudusan saja, tetapi harus menjadi fondasi orang percaya untuk melayani. ${ }^{6}$ Dengan kata lain, kuasa untuk pelayanan yang transformatif (setidaknya dalam konteks ini adalah transformatif komunal).

Sebuah usaha mentransformasi juga merupakan karya Roh Kudus yang dapat dilihat jelas di dalam kehidupan orang percaya dan juga gereja Tuhan. Shelton menulis bahwa dengan melihat hubungan Yesus dengan Roh dimana pelayanan mesianiknya dapat terlihat, sebetulnya memberikan gambaran atau tuntunan bagaimana orang percaya juga harus melayani dan bergantung kepada Roh Kudus. ${ }^{7}$ Artinya apa? Kalau pelayanan Yesus dipandang sebagai sebuah pelayanan yang transformatif, maka sudah sepatutnya orang percaya yang dipenuhi oleh Roh 
Kudus juga melakukan pelayanan yang transformatif. Dengan nada yang sama, Stronstad menulis bahwa seseorang bisa memparalelkan pelayanan Yesus dengan pelayanan para Rasul di kitab Kisah Para Rasul untuk mengatakan bahwa orang percaya memiliki pelayanan profetik yang sama dengan yang dimiliki Yesus. ${ }^{8}$ Lebih lanjut, dasar untuk mengklaim sebuah pelayanan yang paralel dengan Yesus terletak sekali lagi di dalam Kisah Para Rasul 1:8 dimana Allah memberikan janji dan sebuah perintah. Para murid diminta menunggu untuk menantikan janji Roh Kudus itu agar mereka dimampukan dalam melaksanakan tugas dari Yesus. Atas dasar janji inilah, pekerjaan Kristus dan pekerjaan para murid menjadi begitu terikat dan bertalian dengan Roh Kudus, dimana pengurapan Yesus akan dicurahkan kepada orang-orang percaya. ${ }^{9}$

Warrington menjelaskan bahwa ada 4 hal bagaimana Roh Kudus bertalian dengan kehidupan orang percaya: Roh Kudus memberdayakan orang percaya, Roh Kudus menciptakan komunitas, Roh Kudus menginsafkan manusia akan dosa, Roh Kudus mentransformasi orang percaya, Roh Kudus menuntun orang percaya, dan Roh Kudus memberikan karunia-karunia-Nya di dalam gereja. ${ }^{10}$ Karena keterbatasan cakupan penelitian ini, maka akan dibahas apa maksud Warrington dimana Roh Kudus mentransformasi orang percaya.
Warrington menjelaskan dimana Yesus menggunakan metafora air untuk menjelaskan mengenai Roh (Yoh. 3:5, 839). ${ }^{11}$ Dan air ini secara ilmu biologi, sama seperti roh, tidak dapat dipisahkan dari vitalitas mahkluk hidup (Kel. 17:1-6). Sekata dengan itu, orang percaya di dalam Perjanjian Baru ditawarkan sebuah perubahan taraf kehidupan ke arah yang positif (2 Kor. 3:16-18; Ef. 1:3-14). Paulus bahkan menulis mengenai buah Roh yang dihasilkan dari kehidupan orang percaya sebagai buah keselamatan (Gal. 5:22-24; 2 Pet. 1:4-8). Kaum Pentakosta juga mempercayai bahwa Roh Kudus terlibat di dalam proses keselamatan ketika seseorang bertobat (Yoh. 3:6) dan memulai proses kelahiran baru itu, maka mengikuti proses berpikir yang sama, buah Roh juga diharapkan terjadi sebagai bukti transformasi yang nyata dari pribadi orang percaya tersebut. ${ }^{12}$ Inilah peran serta Pentakosta di dalam transformasi individu. Kuasa Roh Kudus selain dilihat sebagai sebuah karunia pemberdayaan untuk misi, tetapi juga dilihat sebagai karunia trasnformatif yang nyata dan konkrit di dalam hidup orang percaya.

Transformasi yang Roh Kudus kerjakan juga tidak sebatas pada manifestasi buah Roh saja, tetapi sampai kepada transformasi hubungan antara manusia dengan Allah (Rm. 8:16). Paulus menyinggung mengenai "pikiran-pikiran yang berasal dari Roh” (8:5-6), dan juga 
“pembaharuan budi” (12:2; Efe. 4:23; Fil. 4:7-8). ${ }^{13}$ Sebuah pemikiran yang dituntun terus menerus oleh Roh Kudus, dan pada akhirnya menghasilkan keputusankeputusan yang benar dan tepat. Paulus juga menulis efek transformatif dari Roh Kudus dalam konsep kehidupan baru orang percaya (Rom. 6:11). Orang percaya dimampukan untuk menerima realitas yang Hukum Taurat tidak bisa berikan, yaitu sebuah kehidupan baru oleh Roh di dalam Yesus Kristus. Keener mencatat, "bukan daging, bukan usaha manusia, melainkan kuasa transformasi Kristus dan Roh-Nya menghasilkan pekerjaan baik."14 Transformasi kehidupan inilah yang diberikan oleh Roh Kudus dan hal inilah yang memberikan sumbangsih besar dari Pentakosta kepada tubuh Kristus, di mana kehidupan Kristen dipandang sebagai sesuatu yang dinamis dan penuh dengan pengharapan. Warrington menambahkan,

It is better, with many Pentecostals, to acknowledge the possibility that the Spirit can empower believers to function in ways that are beyond their normal powers and/or to enable them to utilize the gifts that they have already been granted as part of their personalities as created by God. After salvation, these gifts and sensitivities may be enhanced and supernaturally energized so as to achieve a higher potential of benefit for others. ${ }^{15}$
Dia menjelaskan Pentakosta siap mengakui adanya sebuah potensi kehidupan yang ditransformasi lebih lagi, baik dalam hal karakter dan juga karunia-karunia pelayanan, yang disebabkan karena pemberdayaan Roh Kudus.

Sampai saat ini peneliti berusaha menggambarkan sebuah dampak transformatif yang diberdayakan oleh pencurahan Roh Kudus kepada kehidupan orang percaya, terutama jika dilihat sejak peristiwa Pentakosta di dalam Kisah Para Rasul 2. Tentu bisa ditulis dan diteliti lebih jauh, dampak transformatif yang dapat dilihat secara empiris di dalam konteks negara Indonesia tempat peneliti berada, tetapi karena keterbatasan waktu dan di luar jangkauan studi ini tidak memungkinkan untuk melakukan hal tersebut; eksplorasi dan penelitian ke arah tersebut terbuka lebar untuk tulisan-tulisan ke depannya. Sekarang, mari dilihat dampak transformatif dari peristiwa Pentakosta secara luas yaitu di dalam eklesiologi gereja dan teologi praktis di gereja Pentakosta sekarang ini.

Di atas peneliti sudah membangun argumen yang dikemukakan oleh Cartledge bahwa Roh dapat dimediasikan lewat ruang dan waktu secara temporal dan ada momenmomen perjumpaan dengan Roh Kudus. Hal inilah yang dipahami oleh kaum Pentakosta ketika mereka mengemukakan eklesiologi yang berbeda sebagai sebuah momen perjumpaan dengan Roh Kudus di 
dalam ibadah- ibadah mereka yang transformatif. Ketika dikatakan transformatif, secara umum bisa dikatakan bahwa orang-orang yang masuk ke dalam ibadah Pentakosta akan merasa berbeda secara liturgi dan juga atmosfir ketika mereka masuk ke ibadah non-Pentakosta. Dengan kata lain, kaum Pentakosta tidak puas dengan liturgi yang diwariskan dari kaum Protestan, tetapi mencari pemaknaan dan perjumpaan yang lebih "intim" dengan Roh Kudus. Kaum Pentakosta berdoa dan meyakini pada ruang dan waktu secara temporal tersebut adanya momen atau arsiran antara realitas yang transenden dengan yang imanen. Penekanan pneumatis menjadi penghubung antara apa yang gereja alami dengan realitas Kerajaan Allah di masa yang akan datang. Keener berbicara mengenai penyembahan sebagai kecapan awal dari masa yang akan datang; dan sikap kaum Pentakosta dalam penyembahan yang begitu emfatik dan dinamis, merupakan ekspresi pengharapan mereka akan suatu yang pasti di masa depan. ${ }^{16}$

$$
\text { Peneliti mengambil dampak }
$$
transformatif peristiwa Pentakosta secara eklesial karena secara kontekstual sebuah teologi itu pertama-tama dihidupi di dalam lingkungan komunal gereja sebelum dia menjadi sebuah ide yang diformulasikan oleh para teolognya. ${ }^{17}$ Chan berkata bahwa sebuah pengalaman eklesial yang memberikan isi atau mengkonstitusi teologi utamanya (primary theology). Berbicara teologi di dalam kerangka bidang eklesiologi penting karena dapat menghindari dua perangkap: menghindari sebuah teologi sebagai hanya objek fakta atau proposisi saja (seperti yang dikemukakan oleh kaum fundamentalis) atau teologi sebagai sebuah pengalaman subjektif saja (dalam hal ini mirip konsep "iman" oleh Schleirmacher). Kedua, menghindari penekanan berlebih kepada sang individu sebagai agen berteologi. Chan berkata proses berteologi sejatinya adalah proses eklesial yang melibatkan umat Tuhan dengan sang teolog itu sendiri. ${ }^{18}$

Meminjam pemikiran Chan, Pentakosta berarti bersifat lebih dinamis dimana mereka berusaha mengkontekstualkan teologi mereka ke dalam bentuk pengalaman eklesial yang dapat dialami dan dirasakan oleh umat Tuhan dan juga teolog-teolognya. Aspek inilah yang peneliti pikir adalah sisi transformatif peristiwa Pentakosta kepada eklesiologi. Land juga turut menyumbang pemikiran yang serupa, "The Pentecostal concern...to emphasize the lived reality of the faith, the life and the service of the people of God who are organically constituted as the body of Christ by the indwelling of the Holy Spirit..."19 Penekanan Pentakosta adalah menghidupi iman itu secara komunal dan tidak hanya kepada ortodoksi kebenaran doktrin semata.

Dari semua aspek liturgi yang bisa dibahas di dalam tulisan ini, aspek 
penyembahan bisa dilihat sebagai salah satu yang sentral di dalam teologi Pentakosta. ${ }^{20}$ Cartledge menulis bahwa umat Pentakosta menyembah di gereja sebagai mediasi antara Roh Kudus di dalam doksologi, dan Roh memampukan gereja untuk ikut berpartisipasi baik di alam transenden dan juga imanen, dan dengan begitu realitas trinitas dapat dengan penuh dirasakan oleh jemaat gereja. ${ }^{21}$ Di dalam Kisah Para Rasul 2:11, doksologi yang dimaksud adalah glossolalia, walaupun tidak harus selalu demikian. Namun, di dalam hubungan dengan glossolalia inilah kaum Pentakosta menafsir Roma 8:26, di mana Roh Kudus dihubungkan dengan hati manusia yang terdalam di doksologi gereja. ${ }^{22}$ Cartledge menyebut ini mediasi Roh Kudus di dalam liturgi penyembahan.

Apa yang mendasari Pentakosta untuk mengalami sebuah perjumpaan dengan Roh Kudus di dalam setiap liturgi mereka? Pandangan Spirit-Christology mereka berperan penting dalam hal ini. Kaum Pentakosta percaya bahwa "baptisan Roh Kudus" memampukan mereka untuk mengalami secara penuh "full gospel of Jesus Christ." 23 Dalam artian ini, spiritualitas yang dikejar di dalam setiap liturgi adalah adanya sebuah perjumpaan atau lawatan yang khusus dengan Allah, yang dimediasi oleh penyembahan atau juga dengan karunia berdoa dalam roh. Baptisan Roh yang membuat perubahan paradigma yang mendasar tentang kesadaran religius mereka di tengah-tengah liturgi. Akibatnya, liturgi dimaknai sebagai sebuah usaha untuk bersekut secara personal dengan Allah. Tidak mengherankan kaum Pentakosta sejak gereja mula-mula juga berusaha mencari pengalaman supernatural di dalam liturgi mereka (Kis. 4:31).

Argumen kedua, lebih dari sekedar perjumpaan dengan Roh, umat Pentakosta juga menyadari bahwa karunia Roh yang diberikan di dalam 1 Korintus 12-14 adalah dalam konteks korporat atau ibadah komunal. Betul ada kejadian di mana karunia Roh beroperasi di luar konteks ibadah, tetapi jelas dari tulisan Paulus ini konteks komunitas yang menyembah atau ibadah mempunyai ekspektasi manifestasi Roh secara reguler. Penekanan Paulus pada "rupa-rupa karunia" (1 Kor. 12:4) adalah bukan kepada karunia sebagai benda yang didepositkan, tetapi kepada sumber dari yang memberikan karunia ini. ${ }^{24}$ Bahkan Menzies mengobservasi penggunaan kata doron, kata Yunani yang biasanya digunakan untuk menggambarkan pemberian benda atau hadiah kepada sang penerima dan dimiliki olehnya tampak absen dari tulisa Paulus di sini. Paulus lebih banyak menggunakan kata "dikaruniakan penyataan Roh" atau manifestation (12:7) untuk menggambarkan bagaimana Roh itu sendiri bekerja di tengah-tengah gereja. Roh itu sendiri yang memutuskan kapan dan bagaimana karunia itu bekerja di tengahtengah umat sebagai saluran berkat untuk 
membangun tubuh Kristus. Di sini, bisa dilihat fokusnya adalah kepada atmosfir korporat di mana Roh berfungsi untuk membangun tubuh Kristus ketimbang berfokus kepada 1 atau 2 orang individu dengan karunia khususnya. ${ }^{25}$ Inilah yang mentransformasi ibadah Pentakosta menjadi lebih dinamis dan hidup, sebuah ibadah yang akan berbeda dengan liturgi non-Pentakosta, karena keterbukaan terhadap aktivitas rohani sebagai akibat dari pemahaman kristologi-pneumatisnya.

Di dalam sejarah Pentakosta sendiri, kejadian di Azusa Street patut dimasukan sebagai contoh nyata bagaimana dampak transformatif dari peristiwa Pentakosta bisa mempengaruhi satu dunia. Karya dari Douglas Jacobsen menangkap sejarah dan juga pemikiran teologis yang terjadi di era Azusa Street dan seputar era tersebut. Jacobsen menulis Apostolic Faith Mission yang berada di Azusa Street pada tahun 1906 mengalami ledakan kuasa Roh Kudus yang belum pernah dialami sebelumnya dan berlangsung selama 2 tahun. ${ }^{26}$ Banyak orang yang menempuh jarak beratus-ratus mil ke sana untuk merasakan lawatan Roh Kudus. Jacobsen mencatat pada tahun 1925 sendiri di Amerika Serikat ada sekitar 100,000 penganut Pentakosta, tetapi sekarang diperkirakan ada sekitar 300-500 juta penganut Pentakosta-ini hampir mencapai $10 \%$ dari total populasi manusia di dunia ini. ${ }^{27} \mathrm{Hal}$ yang transformatif adalah pada saat liturgi gereja terjadi pada saat itu, umat lintas suku, ras, dan status ekonomi menjadi satu di ruangan yang sempit dan menyembah Tuhan dalam Roh bersama. Menurut peneliti, hal ini sangat transformatif mengingat pada tahun 1906 masih terjadi segregasi di Amerika Serikat berdasarkan warna kulit antara kulit putih dan kulit hitam. Tercatat ada orang kulit putih, Hispanik, hitam, dan Asia yang menyembah bersama. ${ }^{28}$ Dampak dari pencurahan Roh Kudus adalah mentransformasi sebuah gereja dan komunitas malampaui suku, etnis, dan ras; dimana semua orang mendapat akses yang sama kepada hadirat Tuhan. Pengalaman di Azusa Street ini tidak berhenti sampai di situ, tetapi para pengikut Seymour yang keluar dan menyebarkan api Pentakosta itu ke seluruh belahan dunia.

\section{KESIMPULAN}

Peneliti ingin menyimpulkan bahwa peristiwa Pentakosta yang dimulai dari sebuah janji di Kisah Para Rasul 1:8 dan dirasakan dampak transformatifnya pada jaman itu, masih terus dirasakan sampai sekarang. Bahkan sudah dipaparkan bahwa dampak transformatif dari pencurahan Roh Kudus bisa dilihat secara sempit dan luas. Sempit dalam arti adanya transformasi dari setiap individu yang dipenuhi oleh Roh Kudus, dan hal ini memampukan mereka untuk menghasilkan bukan saja buah Roh tetapi memasuki dimensi pelayanan yang paralel dengan apa yang Yesus lakukan. 
Pelayanan kesembuhan, mengusir setan, dan mempercayai adanya manifestasi karunia-karunia Roh pada jaman ini akan mentransformasi komunitas atau lingkungan terdekat dari gereja itu sendiri. Peneliti juga memaparkan adanya dampak transformatif dalam aspek eklesiologi, yaitu perubahan tata liturgis ibadah dari warisan Protestan. Adanya peristiwa Pentakosta mengubah cara beribadah gereja Tuhan seperti yang nampak pada kejadian di Azusa Street, dan bahkan jika ditarik sampai ke jaman sekarang, ada perbedaan-perbedaan yang mencolok dari liturgi ibadah Pentakosta dan non- Pentakosta. Salah satu aspek liturgis yang transformatif adalah adanya sebuah penekanan kepada pengalamana religius yang betul-betul dimaknai oleh umat. Umat Tuhan mengusahakan atau menggumuli sehingga kehadiran-Nya dapat dirasakan secara temporal dan spasial di dalam realitas sekarang ini.

\section{DAFTAR PUSTAKA}

Cartledge, Mark J. The Mediation of The Spirit: Interventions in Practical Theology. Eerdmans Publishing. Grand Rapids, 2015.

Chan, Simon. Grasssroots Asian Theology: Thinking The Faith From The Ground Up. Intervarsity. Madison, 2014.
Fee, Gordon D. Paul, The Spirit, and The People of God. Baker Academic. Grand Rapids, 1994.

Jacobsen, Douglas. 2003. Thinking in The Spirit: Theologies of The Early Pentacostal Movement. Indiana University Press. Bloomington, 2003.

Keener, Craig. Gift and Giver: The Holy Spirit For Today. Baker Publishing Group. Grand Rapids. Diterjemahkan oleh Helda Siahaan dan Nancy Pingkan Poyoh. 2015. Gift and Giver: Mengenali dan Mengalami Kuasa Roh Kudus. Literatur Perkantas. Jakarta, 2001.

Land, Steven J. Pentecostal Spirituality: A Passion for The Kingdom. Sheffield Press. Wiltshire, 1993.

Menzies, William H. dan Robert P. Menzies. Spirit and Power: Foundations of Pentecostal Experience. Zondervan. Grand Rapids, 2000.

Menzies, William H. dan Stanley H. Horton. Bible Doctrines: A Pentecostal Perspective. $2^{\text {nd }}$ Rev. ed. Gospel Publishing House. Springfield, Missouri, 2012.

Twelftree, Graham H. People of The Spirit: Exploring Luke's View of The Church. Baker Academic. Grand Rapids, 2009. 


\section{Warrington, Keith. Pentecostal Theology: A}

\section{Theology of Encounter. T\&T Clark.}

New York, 2008.

${ }^{1}$ Cibiran dari masyarakat sekitar yang mengatakan mereka mabuk oleh anggur dibantah oleh Petrus karena hari masih pukul Sembilan dan belum waktunya untuk minum anggur (Kis. 2:10). Malahan Petrus langsung dengan otoritatif mengutip Yoel 2:17-21 dan memaknai peristiwa itu sebagai penggenapan nubuatan nabi Yoel.

${ }^{2}$ Mark J. Cartledge, The Mediation of The Spirit: Interventions in Practical Theology (Grand Rapids: Eerdmans, 2015), 93.

${ }^{3}$ Ibid., 93.

${ }^{4}$ Lihat Efesus 1:3, 13-14; 2:8, 22; 3:16, 20; 5:18; 6:17-18. Lihat juga Gordon D. Fee, Paul, The Spirit, and The People of God (Grand Rapids: Baker Academic, 1994), 9-23.

${ }^{5}$ Graham H. Twelftree, People of The Spirit: Exploring Luke's View of The Church (Grand Rapids: Baker Academic, 2009), 80-81.

${ }^{6}$ William W. Menzies \& Stanley H. Horton, Bible Doctrines: A Pentecostal Perspective (Influence Resources, 2012), 124-126. Lebih lanjut, Menzies dan Horton mengatakan petumbuhan kerohanian seseorang lebih maksimal ketika mereka ada di dalam ladang pelayanan. Sehingga jelas bahwa Pentakosta merupakan precursor atas perubahan hidup seseorang yang lebih dinamis lagi.

${ }^{7}$ James B. Shelton, Mighty in Word and Deed: The Role of The Holy Spirit in Luke-Acts (Peabody: Hendrickson, 1991), 59-61.

${ }^{8}$ Stronstad, The Prophethood of All Believers, 16-17.

${ }^{9}$ Cartledge, Mediation, 90. Ia menjelaskan bagaimana adanya kesamaan antara pencurahan Roh Kudus kepada Yesus untuk memenuhi panggilan mesianiknya dengan pemenuhan para murid ketika mereka diminta menunggu: baik Yesus dan para murid berdoa, dan Roh itu "turun" dalam bentuk manifestasi fisik. Dalam satu sisi Yesus dibaptis oleh Yohanes Pembaptis untuk mengidentifikasi dirinya dengan bangsa Israel, dan Kristus membaptis para murid dengan Roh Kudus (Kis. 2:33).

${ }^{10}$ Keith Warrington, Pentecostal Theology: A Theology of Encounter (New York: T\&T Clark, 2008), 5670.

${ }^{11}$ Ibid., 62.

${ }^{12}$ Ibid., 63.

${ }^{13}$ Craig Keener, Gift and Giver: Mengenali dan Mengalami Kuasa Roh Kudus, terj. Helda Siahaan dan Nancy Pingkan Poyoh (Jakarta: Perkantas, 2015), 57. Keener menjelaskan panjang lebar mengenai kesaksiannya dengan Roh Kudus dimana dia seringkali dituntun untuk berjumpa dengan orang tanpa disengaja yang ternyata pertemuan itu berdampak secara signifikan di dalam arah kehidupannya. Keener menyatakan bahwa Roh Kudus pun sanggup menuntun pribadi sampai kepada level detail seperti itu.

${ }^{14}$ Ibid., 96.

${ }^{15}$ Warrington, Pentecostal, 76.

${ }^{16}$ Keener, Gift, 44. Keener mengatakan bahwa Paulus berbicara tentang Roh sebagai "karunia sulung" (rom. 8:23), dan ini merupakan ekspresi dari Perjanjian Lama tentang tuaian dari panen yang akan dating (Im. 23:10). Secara khusus umat Pentakosta memaknai ini, bahwa liturgi ibadahpun bisa dipandang sebagai sebuah kecapan akan pengalaman penyemabahan di masa datang; sehingga kehadiran Roh Kudus dan kuasa-Nya begitu dinantikan di tengah-tengah liturgi.

${ }^{17}$ Simon Chan, Grasssroots Asian Theology: Thinking The Faith From The Ground Up (Madison: Intervarsity, 2014), 15.

${ }^{18}$ Ibid., 17.

${ }^{19}$ Steven J. Land, Pentecostal Spirituality: A Passion For The Kingdom (Wiltshire: Sheffield Press, 1993), 33.

${ }^{20}$ Keener, Gift, 38-45. Keener membahas mengenai Roh yang memperlengkapi orang percaya untuk penyembahan. Dia membahas lebih detail penyembahan Pentakosta secara alkitabiah dan juga kesaksian dia pribadi mengenai kuasa Roh di dalam liturgi ibadah gereja; Land, Pentecostal, 113. Land berbicara mengenai kaum Pentakosta yang menganut "total body life worship" dimana setiap orang mempersembahkan tubuh untuk mengikuti tuntunan Roh Kudus di dalam liturgi ibadah.

${ }^{21}$ Cartledge, Mediation, 109.

${ }^{22}$ Ibid., 112.

${ }^{23}$ Chan, Grassroots, 106.

${ }^{24}$ William W. Menzies dan Robert P. Menzies, Spirit and Power: Foundations of Pentecostal Experience (Grand Rapids: Zondervan, 2000), 183-184. 
${ }^{25}$ Ibid., 184. Menzies menulis bahwa dalam konteks ini Paulus ingin menaikkan derajat peyembahan di atas ritual dan rutinitias religius semata. Penekanan kepada berbagai karuna, membuka pintu untuk orang percaya masuk kepada pelayanan Roh, ketimbang sekelompok orang percaya yang bergantung hanya kepada 1-2 orang praktisi Roh. Di surat lain kepada Timotius (1 Tim. 4:11-16), Paulus juga menekankan keseimbangan antara objektif dan subjektif; antara pembacaan dan pengajaran dengan manifestasi karunia Roh.

${ }^{26}$ Douglas Jacobsen, Thinking in The Spirit: Theologies of The Early Pentecostal Movement (Bloomington: Indiana University Press, 2003), 57.

${ }^{27}$ Ibid., 9 .

${ }^{28}$ Ibid., 63. 